\title{
Partnering with tribal nations during a disaster
}

\author{
B. Selzler, L. C. Patton \& E. Iron Eyes \\ North Dakota State University, Fargo, \\ North Dakota and Consultant to Standing Rock Sioux Tribe, Westat, USA \\ Standing Rock Sioux Tribe, USA
}

\begin{abstract}
Partnerships are essential to disaster recovery. U.S. Government and American Indian Nations live on mutual soil and must partner when disasters occur. However, they have a long history of broken promises and lost trust. The government-to-government policy initiated by President Clinton in 1994 was first used in disaster management on a small Sioux reservation in the northern plains of the U.S. The government-to-government policy is demonstrably effective when disaster planning and practices are culturally congruent with Tribal nations' values and lived realities. This paper explicates cultural congruence of the government-to-government policy with the history of the Sioux Tribe and highlights recent improvements in disaster recovery efforts resulting from use of the 1994 policy.

Keywords: American Indian, reservation community and disaster, governmentto-government, policy, Sioux Nation.
\end{abstract}

\section{Evolution in American Indian, U.S. Government partnerships}

It is widely acknowledged that partnerships are critical when undertaking disaster recovery efforts and essential to effective disaster preparedness planning. American Indian people are the first Americans and as such have a unique relationship with the U.S. Government. The U.S. Government and American Indian Nations live on mutual soil and must partner when disasters occur. And yet, the history of collaborative efforts in this area has been marked by poor disaster preparedness, a lack of resources for rebuilding when disasters strike 
reservation lands, and a legacy of "collective grief" that make disaster recovery especially difficult for American Indians [1].

During a disaster response, Tribal nations, states and the federal government look at existing agreements and partnerships as the foundation and authority to provide services to reservation residents. A sovereign nation has inherent rights to: (a) define itself and its citizens, (b) authority to govern tribal members and forma alliances with other nations, (c) apply its jurisdiction over the internal legal affairs of its citizens and subparts (such as states), (d) claim political jurisdiction over the lands within its borders, and (e) define certain rights that inhere in its citizens (or others) [2].

Historically, the relationship between the U.S. Government and American Indian tribes has been one of individual negotiation between the government and each tribe. These arrangements foster great disparity between tribes in terms of eligibility for government-supported resources, particularly since how membership statuses are determined differ from one tribe to another. For some tribes, status is determined by the land they hold in common; others have no land but maintain close social and cultural ties. Some American Indians have no affiliation with a tribe, but retain federal benefits because they are descendants of previous beneficiaries.

Today, American Indian tribes have a government-to-government relationship with the federal government, and the US Government officially recognizes over 560 American Indian tribes and Alaska Native villages. The influence of this policy on contemporary practices is seen in recent disaster recovery efforts between the Sioux tribal nation members and the Federal Emergency Management Agency (FEMA) in the late 1990s and early 2000s. The unique U.S. Government-to-tribal-government relationship is founded on the principle of tribal sovereignty and treaty negotiation and ratification [3].

Although the government-to-government policy has been in existence since 1994, it was not until 1997 that the policy was used and put into guidelines that structured relationships between the Federal Emergency Management Agency (FEMA) and tribal governments. Severe winter storms, tornadoes, and floods which occurred during 1997-1999, and again in 2007, devastated homes, reservation properties, and multiple resources in the Dakotas and Northern Plains areas. Operationalizing the government-to-government policy during disaster recovery efforts tested the strength of the policy and of the evolving partnerships. The results are promising. Tribal leaders voiced an appreciation of the change in policy and operations that "so diligently and expeditiously" provided financial assistance to tribal members affected by winter storms and spring floods in 1997 [4]. Although they stated that the policy "is long overdue," tribal leaders appreciated efforts made by FEMA to create a relationship which is flexible and dynamic enough to provide for the evolution of partnerships between FEMA and tribal governments. "The [National Congress of American Indians] applauds such a goal" [4].

While these events underscore the idea that understanding the cultural backgrounds of American Indians is essential to helping them recover after disaster strikes [1], other key lessons are illuminated in the evolving nature of 
government-to-government partnerships. Partnerships between nations are valuebased. Partnerships are influenced by the individuals involved, their culture, and choice of expression and understanding of policy. Historical relationships present another layer when negotiating agreement. In American Indian culture events are seen within the context of the community.

Federal and state government representatives as well as tribal leaders recognize that the government-to-government policy relies on mutual respect, meaningful consultation, and collaborative practices in response to disasters. Today's culturally congruent disaster recovery and planning policy required an understanding of past trauma in US-American Indian relationships and how salient elements of the sociopolitical culture of American Indians could be incorporated into the policy. The cursory discussions of the historical trauma, key cultural and sociopolitical elements in Sioux tribal societies, and threshold events in US Government to American Indian relations which follow highlight the interplay between these critical elements.

\subsection{Historical trauma to indigenous societies}

The status of partnering between the U.S. Government and Tribal nations in the U.S. is best understood within the context of the over 200-year relationship. Prior to the U.S. becoming a Nation, the tribes made treaties and exchanged goods with European traders on a regular basis. The Sioux, for example, had contact with Jesuit missionaries as early as 1640 and French traders noted Sioux presence in $1660[5,6]$.

As Euro-Americans moved west, the Sioux moved into the plains area and acquired horses from the Arikara. Although anthropologists studied the Sioux prior to the reservation era, much of what is known today dates to the 1930s. By that time nearly fifty years of U.S. federal Indian regulations and laws had been in place, and the original Indian culture had been all but destroyed. Much of what is known of the prior culture has been reconstructed through AngloAmerican anthropologists and American Indian interpreters.

Originally, the Sioux social structure was dynamic and small bands formed and reformed continuously. Family ties with both parents were important to the Sioux. Commitment to ones' people or the tiospaye, defined as one's large, extended family, was highly valued. The band or group, united under one leader, was the smallest unit of organized, sociopolitical structure. A kinship relationship existed between the groups of 10 to 20 families who constituted the tiospaye. Shared values and beliefs about roles and social structure were held by the members of the tiospaye and were strictly adhered to and considered healthy for all [6-9]. In order to survive, members of the tiospaye had to be cooperative. The community needs were prioritized before individual needs. When the Sioux were forced to move to reservations by the U.S. Federal government, their way of life changed dramatically.

The Euro-American quest for acquisition of land was in direct conflict with the value system of the American Indians. American Indians saw themselves as simply another part of the natural world. There was no reason to own or divide up land, because the land was part of their spiritual system, and it would provide 
for their needs. American Indians placed great value on being in harmony with nature and believed that the accumulation of wealth and/or land beyond one's immediate needs was sacrilegious $[10,11]$.

\subsection{U.S. Government efforts to eradicate American Indians' culture and sociopolitical structures}

The reservation system was established in the 1850 s as places to relocate American Indians who had been removed from their homelands. There were several purposes for these relocations (a) removal of the American Indians opened land for the westward moving Euro-Americans, (b) as wards of the federal government, they were to be acculturated into the dominant society, and (c) in the process, intentional efforts were made to destroy the cultures of the various tribes. The combination of ethnocentrism and ignorance of EuroAmerican educators and policy makers about American Indian culture hastened the loss of American Indian wisdom, traditions and language [12, 13].

\subsubsection{Aggressive assimilation efforts on northern plains reservations}

In 1862, the Sioux tribes were settled on reservations in the northern plains territory that was established by the U.S. Government. During the late 1870s the governmental priorities for Indian policy were to break up the "savage" life of the American Indians and teach them to be farmers and herders [6]. In addition, all American Indian children were required to attend school where they were taught to aspire to the culture of Euro-Americans, that is, to foster pride in individual ownership and to desire independence from tribal control [14].

Initially, geographic areas given to the Sioux were considered uninhabitable and, thus, undesirable to Euro-Americans. Government policy was to make American Indians self-sufficient through farming. Tribal holdings were broken up and parcels of land were assigned to each member of the tribe. Seed and other supplies were available at the government store on a reservation. American Indians were expected to pay for all goods and services received from the store at the end of the year from the monies earned through harvest [13].

Historically, the Sioux manifest strong traditions in regard to hospitality; no one comes to a home without being offered food. This tradition of hospitality meant that families shared resources. Those who saved and stored vegetables for the winter feely gave to those who did not have resources $[11,13]$. Generosity to others was perceived to be as important as personal bravery [15].

The value of hospitality, respect for persons, and meeting the needs of the community first and the individual second continue to be present in many Sioux communities today [13]. The four value orientations toward American Indian and Anglo American lifestyles held today are: traditional, transitional, bicultural and marginal [16]. All four of these orientations were found on northern plain reservations; however the Sioux tend to follow more traditional ways $[13,17]$.

The loss of traditions and rituals and the effect of structured conflicts between U.S. and American Indians' cultural beliefs were traumatic. Scars inflicted during such traumas are slow to heal. Researchers [3, 13] find that leading factors in the present health, social and economic problems faced by American 
Indian Nations are significantly related to mandated residence of American Indians at boarding schools, the loss of the Sun Dance, a spiritual ritual, and the imposition of confusing U.S. Government policies and practices on American Indian cultures.

\subsubsection{Boarding schools}

By the late $1800 \mathrm{~s}$, more aggressive means of assimilation ware put in place by the federal government and, by the early 1900s, American Indian children were required to attend boarding schools at the age of 6 or 7 . If parents resisted this order and refused to place their children in boarding schools, they were punished by loss of food allotments or imprisonment. At the school, use of native language was forbidden and only English was permitted for all conversations. Failure to obey this rule resulted in corporal punishment. Almost without exception, the boarding school experience was extremely difficult for American Indian children because of the harsh regime that was imposed upon them $[5,13,18]$.

Many children who attended these schools lost their native language and knowledge of their culture and history. Sioux children in the northern plains continued to attend boarding schools until after 1935. The boarding schools were conducted in a military fashion with great emphasis placed on timeliness and schedule. It was federal policy that tribal ways should eventually disappear; the required use of English was perceived as key to assimilation of Native children $[5,13,18]$.

Eventually the boarding schools closed and American Indian children were assimilated into existing public schools. Federal monies were provided to community schools for American Indian students, but no methods of accountability were in place to ensure the quality of education [12].

\subsubsection{Sioux religious activities and the Sun Dance}

Historically, the Sun Dance was an important religious ritual of the Plains Indians and was an extremely important part of Sioux religion. American Indian religious activities were banned by the U.S. Government as early as 1883 [5, 6, 11]. By 1885, missionaries pressed the federal government to also ban the Sun Dance, because they considered it a pagan ritual. The element of self-torture in the Sun Dance was seen as detrimental to the effort to civilize and convert American Indians to Christianity [5-7]. Banning the Sun Dance and converting the Sioux to Christianity were integral to the efforts made to assimilate American Indians into the Euro-American lifestyle.

\subsubsection{Evolution of government relations and the Bureau of Indian Affairs}

Because of the treaty agreements between the U.S. Government and the different American Indian tribes, the Bureau of Indian Affairs (BIA) was established in 1832 to provide a liaison between the federal government and the American Indian tribes. Initially the BIA was administered solely by members of the dominant culture, however, over time more American Indians have been employed by the BIA to carry out federal policy [5]. The BIA was the main governing body for reservation residents until 1934 when the Indian 
Reorganization Act (IRA) was passed by Congress. Under this Act the federal government placed more control in the hands of the tribal members.

American Indian religious freedom was not protected until 1978 when Congress passed the American Indian Religious Freedom Act [14]. During the 1960s and 1970s, government policy changed from one of paternalism to American Indian self-determination. The intent of the Indian Self-Determination and Education Assistance Act of 1975 (Public Law 93-638) was to return the authority of government and control of services to the tribes. This Act allowed tribes to assume responsibility to contract for health, social and other services, however the BIA continued to have control over federal monies spent on the reservation for health and education.

\subsection{Tribal government and governance}

In order to be elected to the tribal council at this time, an individual must be 25 years of age or older. All terms are of 2 years duration, at which time, all members stand for re-election again and continuity may be lost. Although tribal leaders have responsibility for decisions over daily issues, strong input continues from federal agents and the BIA to monitor the tribes.

Tribal government based on the U.S. Constitution turned hunters into politicians. Those who could get along with both Anglos and American Indians, and who have good command of the English language, were given the job of leadership. Today tribal government leaders pursue legislation in Congress on behalf of the tribe to establish laws, policies and procedure on the reservation and to invest tribal capital in business ventures [5, 19]. Members of the tribal council are often viewed as intermediaries between the tribe and the federal government. Those who are perceived as being able to gain something for the tribe are elected. However, their roles as leaders may be seen as marginal by members of their own community, largely because of their ability to function in both worlds [5].

On many reservations, several governing bodies are in place simultaneously, and the political structure may be complex and confusing. The presence of BIA staff is still very visible on the reservation, especially since they have the responsibility to oversee federal health and education funds that are to be used on the reservation. The tribal council has control over policy and issues that affect American Indian land and inheritance issues. As a result, tribal government presents a complex picture.

Deloria and Demaillie [3] identified two internal factors that affect tribal government: tribal customs and tribal clans. While the tribal council may provide leadership over day-to-day operation of the community, the clans govern various tribal customs and traditions. Clans handle specific problems, and local issues may not be presented to the tribal council but are handled by the clans. Customs for the tribe are determined by clan behaviour. Thus the entire tribe may be affected by clan decisions about behaviour without issues being presented to the tribal council.

Until 1955 BIA staff were the only governing body on the reservations; however, under the provision of 42 U.S.C. 2004a, a tribal council and the Indian 
Health gained authority from the federal agencies (i.e., BIA and IHS) in regard to how and who controls the resources of the reservation, in spite of the Indian Organization Act of 1934 which gave authority to the tribes to govern themselves.

\section{U.S. Government-to-tribal-government policy}

A policy memorandum issued by President Clinton on April 29, 1994 directed agency and department heads in the U.S. Federal Government to develop guidelines to ensure a government-to-government relationship with federally recognized tribal governments. Ironically, the directive was drafted without input from the Tribal nations.

One Northern Plains Sioux tribe, the Standing Rock Sioux Tribe, was the first to test the government-to-government policy in June of 1997. The Director of the Federal Emergency Management Agency (FEMA) initiated dialogue with the Standing Rock Sioux regarding a disaster management partnership between the Tribe and the Federal Government. As a result of the dialogue between the FEMA and the Standing Rock Sioux Tribe, other American Indian Tribes and Alaska Native Tribes commented on and participated in the development of policy related to when a disaster occurs on Tribal land. The final policy describing the role of FEMA and government-to-government relations with American Indian and Alaska Native Tribal Governments addresses the intent and spirit of partnership in times of disaster. The FEMA vows to develop a continuous and ongoing partnership with American Indians and Alaska Natives to prepare them for response, recovery and mitigation of disasters.

FEMA recognizes and acknowledges that those American Indian and Alaska Native Tribal Governments recognized by the U.S. Federal Government have the rights and benefits of sovereign nations. This policy does not speak to those tribal entities not recognized by the U.S. Government. Essentially this policy gives the FEMA the authority to work directly with Tribal Governments regarding emergency management programs. The following are main points of the government-to-government policy that the FEMA commits to and selected activities done to ensure compliance to the policy:

1. The FEMA agrees to consult with American Indian and Alaska Native Tribal Governments before taking actions that affect federally recognized Tribal Governments. Tribal Governments have the jurisdiction to set goals and priorities for the tribal members and to enter into and fulfill agreements with other partners during a disaster. Consultation is key to a partnership with Tribal nations. Tribal leaders have often asked for more participation in the consultation process with the U.S. Government as well a mechanism to hold the U.S. Government accountable when Tribes are not included in policy development or when the U.S. Government fails to fulfill an agreement. This continues to be a controversial issue.

2. The FEMA recognizes the need for a trust relationship between the Federal Government and American Indian and Alaska Native Tribal Governments. That relationship is bound by specific treaties, court decisions, statutes, 
executive orders, regulations, and policies. The FEMA will acknowledge and take into consideration the impact of policies, programs, and activities on Tribal trust resources. Consideration of the Tribal Governments rights and concerns will be part of the decision making process. Because the trust relationship has been a tenuous one, much work needs to be done to successfully create a partnership between Tribal Government and U.S. Government. During the 1997 disaster representatives from FEMA and Standing Rock Sioux Tribe met on a regular basis to discuss the needs of the Tribe. FEMA staff recognized the need to understand the culture, including the political and clan system. Staff spent time on the reservation, learned the customs, attended local social events and attempted some of the language.

3. The FEMA recognizes that there may be legal, procedural, organizational, or other impediments that affect its working relationships with Tribes. Tribal council is the "Congress" for Tribal nations. Changes in policy must go through Tribal council and a person who is accepted by the local community is needed to be the culture broker. FEMA hired staff from the Tribe that was able to guide them in a culturally congruent manner.

4. The FEMA will work in an interagency partnership to implement its Tribal policy and to work with Tribal Governments in a government-togovernment relationship. FEMA initiated meetings held on the reservation that included local, county, state and federal partners in disaster recovery. For some agencies, this was the first time they had a partnership with particular entities. Those meetings and subsequent collaboration laid a foundation for future collaboration and collegial partnerships. Many of those partnerships exist today.

5. The FEMA recognizes that effective emergency management requires mutual cooperation, partnership, and consideration of neighboring Tribal, State, or local governments. In the field of emergency management, problems are often shared and partnerships often serve the best interests of all. From a cultural standpoint it was essential to have persons recognized as spiritual leaders and cultural leaders from the Tribe at the meetings. These individuals kept the spirit and needs of the Tribe in the forefront. Discussion and subsequent decisions were made with acknowledgement of the perceived needs of the community and the effect on culture.

6. The FEMA acknowledges previous policy commitments and decisions of the United States Government [20]. It was important to have a government agency recognize that previous treaties and agreements were not always kept. FEMA staff was careful to not promise what they could not deliver and to be respectful of the historic pain of this tribal community. Respect is a key tenet of the Sioux culture.

\section{Advancing the government-to-government policy}

The government-to-government policy continues to be reviewed and updated with the last review occurring in March of 2006. More use of the policy and 
more American Indian and Alaska Native Tribe discussion will enhance the usefulness and practicality of the policy for our first Americans.

In consideration of historical and contemporary events and developments the authors offer the following summary recommendations for establishing effective disaster recovery policies and practices with tribal nations:

1. Have knowledge of the culture, including the political and clan system.

2. Speak the local language or have some mechanism of understanding the language.

3. Meet with the community members to identify the needs of the community as perceived by the community. The Tribal council or representatives from the council should know when and where you are on reservation land.

4. Establish an advisory committee to guide you in culturally congruent behavior. Take the time needed to understand and behave in a culturally congruent manner.

5. Go to the reservation for meetings. Ensure you have a spiritual/cultural guide at the meetings. Show great respect for elders.

6. Be sensitive to issues of confidentiality and scrupulous in attending to them.

7. Share appropriate information with the community in a forum the community is familiar with.

8. Have Tribal representation from council, culture (clan) and spiritual realms with you when you meet with the community.

9. Partnerships must be useful and practical to the community.

10. Give the community time to trust you; the key is to have a relationship prior to the disaster.

11. Explore the community language to further explicate words or terms that give you greater understanding of the culture and value system. [21].

Historical distrust and broken promises between the U.S. Government and American Indian Tribes provide a tenuous foundation for future policy. However, with the advent of a government-to-government policy and a desire to provide better emergency management services to reservation residents both the FEMA and Tribal Governments are moving to a new paradigm of collaboration. The model of partnership exhibited by the Northern Plains Standing Rock Sioux Tribe and FEMA during recent natural disasters provides a blueprint for creating enduring partnerships with Tribal nations during disasters.

\section{References}

[1] Bender, E. Disaster response for Native Americans complicated by history, money. Psychiatric News, 38(6), p.8, 2003.

[2] Barrett, C. Sioux, in Markowitz, H. (Ed.), Ready reference: American Indians Salem Press: Pasadena, CA, pp. 2-14, 1997.

[3] Deloria, V., Demallie, RJ (eds.) Documents of American Indian Diplomacy: Treaties, Agreements, and Conventions, 1775-1979 (Legal History of North America, 4). University of Oklahoma Press: Norman, OK, 1999. 
[4] Federal Register, Federal Emergency Management Agency, Statement of Considerations of Comments Received, 64(7), p. 2100, 1999. Online:http://bulk.resource.org/gpo.gov/register/1999/1999_2100.pdf

[5] Powers, W, Sacred Language: The Nature of Supernatural Discourse in Lakota. University of Chicago Press: Chicago, IL. 1986.

[6] Walker, 1982 The structure of society. In R. Demallie (Eds.), Lakota Society (pp. 3-50). Lincoln: University of Nebraska.

[7] Hassrick, R. The Sioux, University of Oklahoma Press: Norman, OK, 1964.

[8] Mohutt, G. \& Blue, A. 1982. Primary prevention as it relates to traditionality and empirical measures of social deviance. In s. Manson (Ed.) New directions in prevention among American Indian and Alaska Native communities (pp. 91-118). Portland: Oregon Health Sciences University, National Center for American Indian and Alaska Native Mental Health Research.

[9] Powers, 1975. Oglala religion. Lincoln, Ne: University of Nebraska Press.

[10] Brown, J. Roots of renewal in Cates, W. (ed.), Seeing with the Naked Eye. Harper \& Row: New York, pp. 25-34, 1977.

[11] Ingram, M., Ethnonursing and ethnohealth. Unpublished dissertation. Salt Lake City: University of Utah: Salt Lake City, 1989.

[12] Ahern, W. To Kill the Indian and Save the Man: The Boarding School and American Indian Education in Ahern, W. (Ed.), Fort Totten. State Historical Society of North Dakota: Bismarck, ND, pp. 23-42, 1986.

[13] Schneider, M. North Dakota's Indian Heritage. University of North Dakota Press, North Dakota Centennial Heritage Series: Grand Forks, ND, 1990.

[14] Buehler, J., 1993. Nursing in rural Native American communities. Nursing Clinics of North America, 28(1), 211-217.

[15] Walker, J. 1991. Lakota belief and ritual. In R. DeMallie \& E. Johner (Eds.), Lakota belief and ritual (pp7-47). Lincoln: University of Nebraska.

[16] Red Horse, J. Family structure and value orientation in American Indians. Social Casework, pp. 67-72, 1980.

[17] Selzler, B. The Health Experiences of Dakota Sioux and their Perceptions of Culturally Congruent Nursing Care. Unpublished dissertation. Denver: University of Colorado: Denver, CO, 1996.

[18] Remele, L. Fort Totten: Military Post and Indian School 1867-1959. State Historical Society of North Dakota: Bismarck, ND, 1986.

[19] Meridith, H. Modern American Indian Tribal Government and Politics. Navajo community College Press: Tsaile, AZ, 1993.

[20] FEMA (2006). http://www.fema.gov/government/tribal/natamerpolicy.shtm

[21] Selzler, B. The Health Experiences of Dakota Sioux and their Perceptions of Culturally Congruent Nursing Care. Unpublished dissertation. Denver: University of Colorado: Denver, CO, pp.194-196 1996. 